\title{
Solidarity in Diversity? State Responses to Religious Diversity in Liberal and Non-Liberal Perspectives
}

\author{
Jaclyn L. Neo*(D), Matthias Roßbach**, Thio Li-ann***(i) and Alexander Tischbirek ${ }^{\star * * *}$
}

(Received 26 August 2019; accepted 29 August 2019)

\begin{abstract}
This Article introduces the German Law Journal's Special Issue on "Solidarity in Diversity? State Responses to Religious Diversity in Liberal and Non-Liberal Perspectives". The major countries in comparative focus are Germany and Singapore, both self-avowedly secular countries that face the challenge of religious diversity: Singapore, from inception, and Germany, through more recent developments. A key issue the Article raises concerns liberal approaches towards regulating religion; it argues that the liberal model, taking Germany as an example, may serve as a productive starting point for comparative analysis, as the liberal focus on individual religious freedom impacts managing religious diversity, shapes national cultural identity, models of secularism and social solidarity. This is compared with non-liberal approaches, as exemplified in Singapore practice, where a more communitarian outlook underpin more interventionist approaches whereby public interests and the common good tend to be prioritized over individual freedom. The comparative angles offered in this Special Issue is furthermore buttressed in several articles in this Special Issue that make comparisons to other jurisdictions-United States and Canada. This introductory Article offers a brief overview to the various contributions to this Special Issue and identifies unifying themes.
\end{abstract}

Keywords: Law and Religion; Religious Freedom; Liberal constitutionalism Non-liberal constitutionalism; Comparative constitutional law

\section{A. Introduction}

Religious diversity is a reality in both Singapore and Germany, albeit in different forms. A 2014 Pew Research study identified Singapore as the most religiously diverse country. About one third of Singapore's population is Buddhist (34\%); $18 \%$ are Christian; $16 \%$ are religiously unaffiliated; $14 \%$ are Muslim; 5\% are Hindu; and less than $1 \%$ are Jewish. The remainder of the population belong to folk or traditional religions (2\%) or to other religions (making up $10 \%$ as a group). ${ }^{1}$ While Singaporean society has been religiously diverse since inception after seceding from

\footnotetext{
${ }^{*}$ Associate Professor, National University of Singapore Faculty of Law.

${ }^{* *}$ Head of "Coordination of Federal and European Policy and International Affairs", State Chancellery of North RhineWestphalia, Berlin Office; Postdoctoral Adjunct Researcher, Humboldt Universität zu Berlin Faculty of Law.

${ }^{* * *}$ Professor (Provost Chair), National University of Singapore Faculty of Law.

${ }^{* * * *}$ Postdoctoral Researcher, Humboldt-Universität zu Berlin Faculty of Law.

${ }^{1}$ Global Religious Diversity: Half of the Most Religiously Diverse Countries are in Asia-Pacific Region, PEW RESEARCH CENTER: ReLigion \& Public Life (Apr. 4, 2014), http://www.pewforum.org/2014/04/04/global-religious-diversity/\#fn20155-2, accessed Aug. 4, 2019. The Pew Research Center's Religious Diversity Index looks at the percentage of each country's population that belongs to the eight major religious groups as of 2010. The closer a country comes to having equal shares of the eight groups, the higher its religious diversity score.
}

(C) The Author(s) 2019. Published by Cambridge University Press on behalf of the German Law Journal. This is an Open Access article, distributed under the terms of the Creative Commons Attribution licence (https://creativecommons.org/licenses/by/4.0/), which permits unrestricted re-use, distribution, and reproduction in any medium, provided the original work is properly cited. 
Malaysia in 1965, German society was, until recently, dominated by the Christian-both Lutheran and Catholic_-faiths. In the middle of the 20th century, around ninety-five percent of the German population belonged to one of the Christian churches. ${ }^{2}$ More than sixty years later, only around fifty-five percent identify as Christians. ${ }^{3}$ Germany scored 5.3 on the Pew's 2014 Religious Diversity Index compared to Singapore's 9.0. Germany therefore looks less religiously diverse than Singapore, with a majority, albeit a small one, professing Christianity. This seemingly lower religious diversity, however, must be understood in the context of German history. After centuries of predominance of one religion, reunification and migration have led to diversification of its society with increased numbers of non-Christian adherents and persons who profess no religious commitment-for example, atheists and agnostics. ${ }^{4}$ As the proportion of Christians decrease and the proportion of non-religious and Muslims increase, religious diversity has become a matter of politics. In particular, the arrival of refugees from Syria and other countries in the last four years has precipitated a public debate about their "integration" into German society-especially with regard to their religious beliefs and practices. This debate pertains to the role of the state in managing emerging conflicts between religions (citizen-citizen) and to the relationship between legal duties and religious beliefs (citizen-state).

Both the Singapore and German states self-describe as secular, though they are by no means of follow a strict separationist approach to secularism. Both states face key dilemmas in managing its religious diversity with the goal of preserving socio-political stability while protecting religious freedom. This includes the question of whether, and to what extent, the Singapore and German states should and do respond to religious diversity and diversification. What should be the overarching objective of such responses? Does the state need to actively manage inter-religious relations in order to ensure the solidarity and long-term sustainability of the state? Are there optimal responses to diversity? What role should the state play where conflicts arise among different religious groups? Can and should the state be responsible for forging social solidarity in light of religious diversity? What are the dangers of a state crafted or endorsed national identity, and how may this affect ethno-religious minorities? In this regard, the Articles in this Special Issue seek to address these multiple questions.

\section{B. Liberal vs. Non-Liberal: A Productive Approach?}

While the protection of diversity is a constitutional command in most modern states, there remains a persistent perception, whether officially endorsed by the state or not, that social diversity complicates common solidarity, even political unity. Some scholars even presume that social and cultural coherence is a "prerequisite for a constitutional state" ${ }^{5}$ Where religious diversity is present, however, state responses can take many forms. One ideological framework differentiates liberal responses from non-liberal responses. The typical liberal response to religious diversity has been for the state to adopt a position of religious tolerance and neutrality. Under this approach, the state seeks to maintain distance from religion; it refrains from advancing any particular vision of the common good. As Paul Horwitz points out, the modern liberal consensus is "at least

\footnotetext{
${ }^{2}$ See Statistisches Bundesamt: Fachserie A / Bevölkerung und Kultur / Volks- und Berufszählung vom 6. Juni 1961, Heft 5, Bevölkerung nach der Religionszugehörigkeit. Stuttgart 1966), at 21, https:/www.destatis.de/GPStatistik/servlets/ MCRFileNodeServlet/DEMonografie_derivate_00001919/FS-A-VZ1961-05-1961-05.pdf, accessed Aug 10, 2019.

${ }^{3}$ Religionszugehörigkeiten in Deutschland 2017, ForschungSGruppe WeLtansCHAUUNGEN IN DEUTSCHLAND (Aug. 10, 2018), https://fowid.de/meldung/religionszugehoerigkeiten-deutschland-2017, accessed Aug. 4, 2019.

${ }^{4}$ The abovementioned study held that $68.7 \%$ of German citizens were Christian, 5.8\% Muslim, and $24.7 \%$ unaffiliated. Pew Research Center, supra note, at 18.

${ }^{5} \mathrm{Cf}$. András Sajó \& Renáta Uitz, Freedom of Religion, in Oxford Handbook of Comparative Constitutional LaW 909, 912 (Michel Rosenfeld \& András Sajó eds., 2015) (citing the work of Ernst-Wolfgang Böckenförde). See also Chapter 16 of John Stuart Mill, Of Nationality, as Connected with Representative Government, in ON LIBERTY AND OTHER EsSAYs 428 (2008).
} 
ostensibly a position of genuine neutrality, in which the state is to take no position at all, whether on matters of religious truth or anything else." 6 Consequently, as Bruce Ackerman, Ronald Dworkin, Paul Jones, and others have analyzed, ${ }^{7}$ such a liberal secular state abstains from interfering with religious activities, insisting on the separation of the state from religion and the neutrality of the state vis-à-vis religion. This liberal approach is most committed to religious freedom as a negative liberty, encompassing the right to have, not have, or change a religion. The secular state does not purport to be the arbiter of religious truth or the champion of orthodoxy, but rather seeks to secure a framework of pacific co-existence and to guarantee the conditions necessary for freedom of religious profession, which falls within the private realm of personal choice.

The non-liberal response to religious diversity, however, does not eschew state intervention but in fact often endorses direct and open regulation of religion in service of non-liberal values such as community interests or to advance a particular vision of communal life. ${ }^{8}$ While non-liberal constitutions are "varied and competing", they are united as a category by their negation of the principal liberal affirmations prioritizing individual rights and endorsing state neutrality. ${ }^{9}$ Thus, non-liberal states overtly privilege substantive visions of the good, which could be based on ethnicity, religion, or communal morality. ${ }^{10}$ They may deploy legal means and non-binding forms of "soft" constitutional law, such as declarations, in seeking to unite religiously diverse groups through a shared commitment to public values, including religious freedom and harmony, fostering a form of "civil religion" as the basis for citizen identity and solidarity. ${ }^{11}$

Both the liberal and the non-liberal approaches have been criticized regarding their ability to tackle the issue of religious diversity. On the one hand, the liberal approach has been criticized for undervaluing the social dimensions of religion. In particular, certain expansions of the liberal claim for state neutrality to require not only that the government be separated from religious authority, but also that religious voices be excluded from the public sphere have attracted criticism. ${ }^{12}$ This exclusionary claim is often attributed to John Rawls. ${ }^{13}$ Reasons provided in the public sphere, it is argued, need to be generally accessible to all persons in society to be accepted as a basis for public action. Accordingly, there are claims that religious viewpoints need to be "translated". ${ }^{14}$ It is worth noting that German philosopher Jürgen Habermas later revised his initial support for this exclusionary view and argued that the "translation proviso" places undue burdens on religious viewpoints ${ }^{15}$; as such, this requirement should only be imposed on public officials and not on members of the public. This shows that the strictly exclusionary

\footnotetext{
${ }^{6}$ Paul horwitz, The Agnostic Age: Law, Religion, And the Constitution 10 (2011) (emphasis added).

${ }^{7}$ For further reading on neutrality and liberalism, see Peter Jones, The Ideal of A Neutral State, in LIBERALISM AND Neutrality 2 (Robert Goodwin \& Andrew Reeve eds., 1989); Bruce AcKerman, Social Justice in the Liberal State (1980); Ronald M. Dworkin, Liberalism, in PubliC AND Private Morality 113-43 (Stuart Hampshire ed., 1978). For the intractability of the "neutral" position, cf. Rex Ahdar, Is Secularism Neutral?, 26 Ratio JuRIS 404 (2013).

${ }^{8}$ Jaclyn L. Neo, Secularism Without Liberalism: Religious Freedom and Secularism in a Non-Liberal State, MicH. ST. L. REV. 333 (2017); Jaclyn L. Neo, Conceptualizing the Regulation of Religion: A Preliminary Framework For Inquiry, in REGULATING Religion in Asia: Norms, Modes And Challenges (38 Jaclyn L. Neo, Arif A. Jamal, \& Daniel PS Goh eds. 2019).

${ }^{9}$ Graham Walker, The New Mixed Constitution: A Response to Liberal Debility \& Constitutional Deadlock in Eastern Europe, 26 Polity 503, 506 (1994).

${ }^{10}$ Graham Walker, The Mixed Constitution After Liberalism, 4 CARdozo J. INT'L \& Comp. L. 311, 319 (1996).

${ }^{11}$ Cf. also Li-ann Thio, Relational Constitutionalism and the Management of Inter-Religious Disputes: The Singapore 'Secularism with a Soul' Model, 2 Oxford J. L. \& ReLigion 446-69 (2012).

${ }^{12}$ Nicholas Wolterstorff, An Engagement with Rorty, 31 J. Religious ETHICs 129, 132-33 (2003).

${ }^{13}$ For this liberal position, see John Rawls, Political Liberalism (Colum. Univ. Press, 2005); John Rawls, The Idea of Public Reason Revisited, 64 U. CHI. L. Rev. 765 (1997); John Rawls, The Idea of an Overlapping Consensus, 7 OXFORD J. LEGAL STUD. 1 (1987).

${ }^{14}$ To be fair, Rawls modulated his earlier claims and restricts this exclusionary position premised upon reasonableness of public reason to what he calls "constitutional essentials."

${ }^{15}$ See Jürgen Habermas, Religion in the Public Sphere, 14 Eur. J. Phil. 1, 4 (2006). Cf. JÜrgen Habermas, Glaube Und WisSEN, ZeITDIAGNOSEN, ZWÖLF EsSAYs (Suhrkamp Verlag 2003) 249-62.
} 
claim attributed to Rawls only reflects one specific form of liberalism. It neither reflects political and legal reality in Germany nor does it represent liberalism in general-which can take many forms. ${ }^{16}$

A more general criticism of the liberal approach sometimes incorrectly refers to the writings of German Constitutional Justice Ernst-Wolfgang Böckenförde who pointed out that the liberal state cannot guarantee its own prerequisites and ensure social solidarity. ${ }^{17}$ Interestingly, while some have attributed to Böckenförde the idea that only religion can guarantee a state-sustaining ethos and relative homogeneity, he later clarified that what he meant is "lived, living culture" which includes religious aspects and often has religious roots, but which can also be overlaid with other things. ${ }^{18}$

On the other hand, critics of the non-liberal model argue that state intervention in religion is often instrumental and serves to maintain political control. This is because religion is seen as a potential basis for mobilization that could be used against the government. As such, it has to be restrained. Accordingly, in the absence of liberal constraints on state power, the restriction of religion is seen as a way to advance and maintain authoritarian government. Religion is restricted and controlled alongside other social forms of association. Furthermore, some claim that any governmental intervention restricts religious freedom and would eventually result in violent persecution. ${ }^{19}$

\section{Germany and Singapore: Unlikely Bedfellows or Strange Soulmates?}

Against this backdrop, one may at first be inclined to see a stark contrast between Germany and Singapore. Singapore is a non-liberal state in the sense that it does not give the greatest priority to individual autonomy within its constitutional order, even though Singapore's constitutional order has clear liberal roots. ${ }^{20}$ Singapore's response to religious diversity testifies to be a system in which the government claims to play the role of a "neutral" arbiter in ensuring peaceful coexistence among the different religious groups, and will intervene in religious affairs and inter-religious interaction, where deemed necessary. ${ }^{21}$ A range of laws exist to manage inter-group relations, though these are employed infrequently. These laws serve a strong public interest in ensuring social solidarity, encapsulated in the idea of "religious harmony". Such public interests_-public order and religious harmony - are invoked frequently and openly to justify the state's restrictions on religious liberty and autonomy. ${ }^{22}$ It is debatable that such a secular but non-liberal regime could nonetheless ensure a high degree of religious freedom. ${ }^{23}$

In contrast, the character of Germany as a liberal state is especially reflected in its approach to individual religious freedom. The German Constitution ascribes an especially vigorous level of

\footnotetext{
${ }^{16}$ John Rawls notes, “[T]here are many liberalisms.” John RaWls, Political Liberalism 223 (1993).

${ }^{17}$ Ernst-Wolfgang Böckenförde, StaAt, Gesellschaft, Freiheit: Studien zur StaAtstheorie Und zum VERFASSUNGSRECHT 60 (Suhrkamp Verlag 1976).

${ }^{18}$ See Ernst-Wolfgang Böckenförde, Biographical Interview, in Constitutional and Political TheORY: SElECted Writings (Mirjam Künkler \& Tine Stein eds. 2017).

${ }^{19}$ See, e.g., Brian J. Grim \& Roger Finke, The Price of Freedom Denied: Religious Persecution and Conflict in the TwENTY-FIRST CENTURY 74 (2010).

${ }^{20}$ For instance, the Singapore constitution contains a bill of rights-Part IV, Fundamental Liberties - that traces its genealogical roots to the American constitution. See Anthony Lester QC, The Overseas Trade in the American Bill of Rights, 88 Colum. L. Rev. 537, 544 (1988); Thio Li-ann, A Bill of Rights Without a "Rights Culture"? Fundamental Liberties and Constitutional Adjudication in Singapore, in Comparative CONSTITUTIONAL LAW: A FESTSCHRIFT IN HONOUR OF Professor P.K. Tripathi (Mahendra Pal Singh ed., 2nd ed. 2006).

${ }^{21}$ Jaclyn L. Neo, Secular Constitutionalism in Singapore: Between Equality and Hierarchy, OXFORD J. OF LAW AND RELIGION 1 (2016)

${ }^{22}$ Li-ann Thio, Rule of Law, Religious Liberty, and Harmony: Multiculturalism, Legal Pluralism, and the Singapore Model of Accommodative Secularism, 5 J. L. RELIGION \& ST. 254 (2017).

${ }^{23} \mathrm{Neo}$, supra note 8.
} 
protection to individual religious autonomy. Germany is not strictly secular, however, because it grants privileges to certain religious communities. This results in a very unique model of cooperation between the church and the state which famously includes religious education in state schools, the collection of church taxes by the state, and-on a more general account-the public law Körperschaftsstatus of some religious communities. ${ }^{24}$

There are also differences in terms of geographical size and religious demography. Singapore is a small unitary republic with a population of less than six million people. In contrast, Germany is a federal republic with a population more than ten times that of Singapore (more than eighty million). At 724.2 square kilometers in land size, Singapore is roughly the size of Germany's second smallest state, Hamburg. There may be strong objections to the idea that Singapore and Germany could be examined in the same breath or even studied comparatively. More particularly, there may be a strong aversion to the idea that liberal Germany could find non-liberal Singapore's approaches instructive in any way. The objective of this Special Issue is not to argue that one country should adopt approaches of the other. Rather, the Articles in this Special Issue seek to test the traditional assertions of the liberal and non-liberal models. Our approach is an instrumentalist and functionalist one.

Articles in this Special Issue examine whether there are similar objectives and desired outcomes in both countries despite their divergent political orientation. In doing so, this Special Issue is able to tease out areas of overlap and differences between the non-liberal and liberal approaches and their state responses to religious diversity. Furthermore, in both countries, questions of shared identity are implicated, but are the state responses to religious diversity distinctive depending on whether religious diversity is an existing condition as opposed to a changing circumstance? In addition, two contributions take a comparative perspective on Canada/Singapore and the US/Germany, respectively, in order to evaluate and shed insight on the German and Singaporean approach to religious diversity, from yet another angle.

\section{Contributions in this Special Issue}

The Articles in this Special Issue take on a "law-in-context" approach and the conviction that legal regulation must theoretically and empirically be informed by social sciences, which especially applies to the challenges posed by religious diversity. The Articles combine a mix of comparative, conceptual, and interdisciplinary approaches applied to the subject of religious diversity and state responses. This is the case even in Articles whose primary focus is on a single-jurisdictional study; these studies are used to interrogate broader issues on the subject. A mix of single-jurisdictional and comparative analysis will allow us to give a more informed answer to broader questions, such as: Are there optimal responses to diversity? What role should the state play where conflicts arise among different religious groups? Can and should the state be responsible for forging social solidarity in light of religious diversity?

The Special Issue opens with a joint paper by Kevin Tan \& Matthias Roßbach providing a comparative analysis of state responses to religious diversity in Singapore and Germany. The authors take on a historical approach, examining the extent to which their different approaches were shaped by these countries' respective pasts. First, the Article discusses the development in Germany and describes four phases of development of the law on the relationship between church and state. Starting with the consequences of reformation, it shows that, for centuries, the relationship between denominations had been the crucial matter of this body of law. Only later, the law dealt with conflicts between religion and atheism. The Article then presents the fundamental rights approach of the Basic Law and analyzes it against the backdrop of the historical development and recent challenges. Second, the Article offers a historical account of Singapore's attempts at regulating and managing religious diversity. It starts with the establishment of a British trading

\footnotetext{
${ }^{24}$ See GRUNDGESETZ [GG] [BASIC LAw] art. 140, translation at http://www.gesetze-im-internet.de/englisch_gg/index.html.
} 
post on the island in 1819 and runs up to the present day. As a result of mass migration in its early years, Singapore was to become, in the twentieth century, one of the most religiously and culturally diverse nations in the world, with all the tensions and frictions that accompany this setting. The Article further shows that Singapore has sought to regulate and manage the various religious groups through a combination of legislation—such as the Mohammedan and Hindu Endowments Ordinance of 1905-and state policy.

Fabius Wittmer \& Christian Waldhoff's intervention focuses on religious education in Germany and the challenges it faces from religious diversification in German society. The Article takes as its starting point the German constitution, which provides that religious education shall be part of the curriculum of public schools. For some time now, there was an established arrangement on the provision of religious education whereby such education in public schools was only offered by the Catholic and Protestant churches. With the decreasing number of Christians and increasing number of Muslims in German society, however, there is increasing stress on this established arrangement. There is now increased demand for Islamic religious education at public schools. Therefore, the question emerged whether the German constitutional law is capable of facing the new challenges of religious diversity. The Article tries to answer this question with regard to the introduction of Islamic religious education as a measure of adaptiveness. In a first step, the requirements of the constitution regarding religious education will be outlined. In a second step, it is examined whether Islamic religious education may be introduced at public schools as a regular subject.

Amandine Barb sheds light on the contemporary political governance of religious diversity in the United States and Germany by analyzing the recent changes in the two countries' respective approach to teaching religion in public schools. The United States and Germany embody two very different models of religious education: On the one hand, American public schools do not include religious education into their curricula-religious education is in fact prohibited by the Establishment Clause of the First Amendment. In Germany, on the other hand, confessional religious education is protected by the Federal Constitution and is regularly taught in most German Länder. Yet, the Article argues, the emergence of assertive "public religions," for example, Evangelical Christianity in the United States and Islam in Germany, poses quite similar challenges for both models. The matter of religious education hence serves as a comparative case study for assessing, on the one hand, the impact of an increasing diversification, and, on the other hand, governmental efforts in controlling and disciplining religious identities in order to make them compatible with the expectations of a secular democracy.

In his Article, Alexander Tischbirek investigates EU law influences on the German constitutional law on religion. By describing the law on religion in multi-level governance as a double conflict of laws, he argues that the existence of strict neutrality clauses in the primary law of the EU cannot prevent the EU from interfering with the member states' law if the EU does not want to abandon central stances of European law. The model of a double conflict of laws is then illustrated by examining a recent controversy between the Court of Justice of the EU and the German Federal Constitutional Court regarding church labor law. The Article argues that EU law steers state-church relations towards a paradigm of non-discrimination. While this adds yet another layer to the classic controversy between a fundamental rights-centered/individualist and a rather collective/institutionalist understanding of the constitutional law on religion, the contribution suggests such a paradigm to be a suitable legal response to religious diversification.

While Tischbirek's investigation provides insights into the implications of multi-level governance at the national and supranational levels, Noor Aisha bte Abdul Rahman's contribution in this Special Issue focuses on another form of diversity governance through a separate personal law regime for a religious minority. Through a close interrogation of Singapore's Muslim personal law regime, Noor Aisha shows that while such an arrangement accommodates religious differences and realizes the aspirations of some Muslims, this may thwart social solidarity in three key ways. First, the state, in relying on officially appointed religious elites as the authoritative voice 
of the community, ends up consolidating one constituency's power and perspectives, sidelining marginal voices. Second, the compulsory personal law regime hinders the equal enjoyment of rights of all citizen, given that the Muslim personal law contains certain gender inegalitarian norms in its administration of marriage-including the legalization of polygamy-divorce, and inheritance. This speaks to the conflict between religious norms and the basic human rights tenet of egalitarianism. Third, the dominant voice of traditional religious elites could produce an antagonism or reservation towards the idea of secular law, viewed as a threat to religious law. Noor Aisha's contribution is crucial in showing that group autonomy schemes may undermine the ideals of equal citizenship, reflecting the tension between the rights of a religious group and the rights of members of that group. Noor Aisha argues that these issues may be mitigated if the Muslim personal law regime is made optional, rather than compulsory, accommodating both individual freedoms and group corporate interests in autonomy and preserving a distinct identity and way of life.

Arif A. Jamal \& Daniel Wong Sheng Jie's Article in this Special Issue further deepens our understanding of how states manage social diversity by discussing Canada in addition to Singapore. The distinctive feature of both these countries is their long-standing explicit commitment to multiculturalism. As the authors observe, Singapore and Canada are in vastly different parts of the world but share some salient characteristics. Both are tremendously diverse in ethnic, racial and-increasingly_religious terms. The Singaporean and Canadian approaches are suited for comparative study because both are premised upon an embrace of diversity rather than an attempt to overcome or eradicate such diversity. ${ }^{25}$ This is reflected in both state and social discourse where the multicultural and multi-religious character of both countries is commonly invoked. Both countries also express an avowed commitment to freedom of religion, which is constitutionally guaranteed. A comparative study of both these countries is furthermore salient for their distinctiveness. Despite a common starting point, the Singaporean and Canadian approaches have taken on slightly different slants, with the former being more managerial than the latter. On one account, the distinctiveness in approaches can be attributed to the Canadian commitment to liberalism, which tends to emphasize the neutrality of the state. Jamal and Wong suggest, however, that there is more than meets the eye and that they reflect different approaches to differentiated contexts.

Jaclyn L. Neo's Article brings another piece of the puzzle to the Special Issue. It reflects on how the idea of religious harmony has been used to maintain peaceful coexistence among different groups in a religiously diverse context. She argues that the idea of harmony is most commonly associated with non-liberal regimes and is therefore often seen as a way for states to subordinate individual interests and rights to wider social—often statist—interests. She argues, however, that harmony is not a unitary concept, and more importantly that groups can internalize harmony such that religious harmony itself becomes more than just a state-imposed norm but also a social norm claimed by groups against other groups and even against the state.

Lastly, Thio Li-ann examines the nature, function, source, and content of a constitutional civil religion (CCR) within Singapore's constitutional experiment in promoting solidarity through recognizing and managing the diversity of race and religion. CCR is constructed by government elites as a strategy to secure social harmony within the world's most religiously diverse polity, through recognizing an "irreducible plurality" in ethnic and religious terms, while maintaining an indivisible unity through nurturing bonds of citizen solidarity. This dovetails with the function of the constitution as an instrument of social integration, involving the articulation and regular affirmation of shared community values and aspirations, as well as process and practices, or public rituals, which regulate dispute resolution or conflict management during instances or crises where racial and religious harmony is threatened. A functional approach is taken towards the idea of a "civil religion", and the tasks of integration, legitimation, and inspiration it may play

\footnotetext{
${ }^{25}$ See Jaclyn L. Neo \& Bui Ngoc Son, Pluralist Constitutions in Southeast Asia (Hart 2019).
} 
within a constitutional order. The nature of civil religion in general, and the sources of CCR in Singapore, as well as its expression as a public ritual in managing religious disharmony disputes, is discussed. To the extent that civil religion can safeguard constitutional guarantees of religious freedom while providing a set of shared norms, practices, and expectations that informs statereligion and inter-religious interactions and dispute resolution, it contributes to promoting solidarity within a diverse, non-liberal communitarian order. Within this, the CCR is used, through exhortation, to produce a certain citizen ethos and internalized attitude towards prioritizing racial and religious harmony; provided the CCR is "thin" or procedural and sustains respect for religious liberties and freedom of conscience, it may arrest fears that the idea of CCR is deployed to advance an authoritarian imposition of state dictated values, devoid of the leavening effect of consultation and citizen participation in the project of national self-identification.

\section{E. Conclusion}

The current debate on religious diversity and the optimal and appropriate responses a state may adopt implicates a wide range of issues, as well as fundamental questions implicating the relationship between the state and religion, the nature of secularisms, national identity, and the parameters within which religious identity, religious pluralism, and religious freedom interact. The comparative approach adopted in this Special Issue seeks to contribute and enrich this debate by adopting what might be viewed as unlikely comparators, going beyond the "usual suspects" 26 in the examination of concepts and approaches adopted to engage, manage, or resolve challenges posed by religious diversity. We hope, too, that the collection of Articles in this Special Issue will also challenge the existing assumptions which inform comparative studies in this field.

Acknowledgements. On behalf of the authors, we would like to thank the Editors of the German Law Journal for entrusting us with this Special Issue. Anna von Oettingen of the Editorial Board has been a highly supportive and patient host. Meghan Prieto and her team have put a lot of work into copyediting this issue. We would also like to thank our student assistantsDaryl Yang, Philip Teo, Louis Lai, and Merle Jungenkrüger. This Special Issue's contributions originate from two workshops held at National University of Singapore and Humboldt-Universität zu Berlin in 2018 that were generously supported with funds from the National University of Singapore and Humboldt-Universität zu Berlin Joint Projects Research Grant.

\footnotetext{
${ }^{26}$ Ran Hirschl, Comparative Matters: The Renaissance of Comparative Constitutional Law 192 (Oxford UNIVERSITY PRESS 2014).
}

Cite this article: Neo JL, Roßbach M, Thio L, and Tischbirek A (2019). Solidarity in Diversity? State Responses to Religious Diversity in Liberal and Non-Liberal Perspectives. German Law Journal 20, 941-948. https://doi.org/10.1017/glj.2019.77 